DOI https://doi.org/10.18551/rjoas.2018-04.26

\title{
THE IMPACT OF KNOWLEDGE AND PERCEPTION TOWARD ENVIRONMENTAL SANITATION BEHAVIOR IN SOCIETY OF SEMARANG CITY
}

\author{
Hidayati Mustikaningrum*, Lestari Sri Puji \\ Faculty of Economic and Bussiness, University of 17 August 1945 (UNTAG) Semarang, \\ Indonesia \\ *E-mail: mustika.mom@gmail.com
}

\begin{abstract}
The purpose of this research is to find out the impact of knowledge and the perception of environmental sanitation behavior in Semarang city. The population in this study is housewives aged 30 to 60 years old in Semarang City. Samples are 100 housewives from the Sumurboto, Ngesrep and Karang Bendo Administrative Village in Semarang City. The research was conducted by using multiple linear regression equation. The results of this study suggest that the impact of knowledge on environmental sanitation behavior is positive and significant. While the impact of perception on environmental hygiene behavior is positive and not significant.
\end{abstract}

\section{Key words}

Environmental sanitation, knowledge, perception, behavior.

Environmental sustainability could be defined as a condition of balance, resilience, and interconnectedness that allows human society to satisfy its needs while neither exceeding the capacity of its supporting ecosystems to continue to regenerate the services necessary to meet those needs nor by our actions diminishing biological diversity (Morelli, 2011). Environmental sanitation is an essential factor that leads to a healthy environment and consequently promotes good health and productivity: also secures peoples' welfare (Ministry of Local Government \& Rural Development, 2010). The world Health Organization (WHO) (2008) defined environmental sanitation as the control of all those factors in man's physical environment, which exercise or may exercise a deleterious effect on his physical development, health and survival.

Sanitation is a reflection for every individual in maintaining the health that is so important in everyday life. Sanitation in other words is a state free of all dirt, disease, and other factors which can harm all aspects of every activity and behavior of the community environment. Human life itself can not be separated both the natural environment and social environment (Nazaruddin, 2014). Sanitation behavior is a manifestation of the actions that people commit to waste, which includes environmentally responsible behaviors such as environmental soiling actions to responsible actions such as maintaining and cleaning the environment (Istiqomah, 2009). One's sanitation behavior in everyday life is an interrelated relationship between behavior and the surrounding environment situation.

Environmental education is considered an appropriate intervention to create awareness and understanding of the challenges of environmental degradation (Ajiboye \& Ajitoni, 2008). The research that has been done by Ririn \& Surahma (2013) shows a very significant relationship between the level of household knowledge through managing garbage in Kaliwungu Subdistict, Semarang District. On the contrary, the research results by Henewa, R. et.al (2014) stated that there is no relationship between Students of Sanitation Practice and environmental knowledge. However, the research results from Anijaobi-Idem, 2015, concluded that environmental awareness is significantly related to school sanitation in terms of class sanitation, school assembly sanctions and the provision of landfills. That is, environmental awareness leads to the maintenance of class sanitation, compound sanitation of schools and the provision of landfills.

People's habits to throw garbage in arbitrary places are difficult to change and the ignorance toward clean and healthy environment resulted in the dirty and polluted 
environment. Housewives have an enormous role in modeling their families in comparison to fathers. Housewives are also more dominant in managing the food menu and maintaining the sanitation of the house, not to mention they also participate in providing education and knowledge and instilling the value of environmental sanitation in the family. High environmental knowledge will make it easier for housewives to keep the environment clean.

The purpose of this research to understand the impact of knowledge and perception of environmental sanitation towards environmental sanitation behavior in the society of Semarang city.

\section{LITERATURE REVIEW}

The concept of environmental sanitation entails the control of water supplies, excreta disposal, waste water disposal, refuse disposal, vectors of diseases, housing conditions, food supplies and the safety of the working environment (Acheampong, 2010). Environmental sustainability could be defined as a condition of balance, resilience, and interconnectedness that allows human society to satisfy its needs while neither exceeding the capacity of its supporting ecosystems to continue to regenerate the services necessary to meet those needs nor by our actions diminishing biological diversity (Morelli, 2011). The Concept of Environmental Sanitation for Maintenance by Soekidjo Notoatmodjo (2007) suggests that environmental health in developing countries ranges from sanitation, drinking water, housing, garbage disposal, and waste water disposal.

Sanitation becomes an important factor to shape the personality of a person, a region and even a nation. Everyone has the right and obligation to clean and healthy environment and garbage is one of the sources of the cause of non-existence of clean and healthy environment, waste management must be carried out consciously, integrated and directed between each individual society and government (Nazarudin, 2014). Environmental sanitation obstacles factors are as follows. 1. Environmental- friendly development costs a lot. 2. The lack of shame culture so that people do not hesitate to throw garbage anywhere, anytime, and in front of anyone 3. lack of knowledge and understanding of society about the dirty environment hazard due to garbage, waste, and pollution. 4. Lack of knowledge about waste utilization and waste management.

Knowledge of environmental issues and appropriate actions to overcome them become one of the prerequisites for responsible behavior. Having knowledge and ability is not enough. Desire to realize the action of environmental sanitation is necessary. One's desires are strongly influenced by personality factors, namely attitude, locus of control and sense of responsibility. Knowledge is also influenced by factors of education, occupation, age, interest, experience, culture, environment, information. Individual knowledge about health risks is known to profoundly influence risk perception which, in turn, affects a person's attitude. Thus, an individual's knowledge, perception, and attitude are fundamental in determining how people behave about environmental hazards (Dhitinut Ratnapradipa, 2011). Results of research by Aswanthy (2015) stated that there is a positive correlation between level of knowledge and standard of practice. However there is no association between knowledge and practices of environmental sanitation and hygiene with selected socio personal variables.

Environmental perception has been defined as information processing system in which individuals actively explores their surroundings and extract and use information in constant interaction between themselves and their environment (Byoung, et.al, 2006). The importance of studying environmental perception stems from the fact that several spects of man's daily living are affected by his perception (Oluwole Daramola, 2016).

The study concluded that for homes and schools to act as correlates of evolving sustainable sanitation behavior among these future adults, teaching on how to develop good hygiene behavior must be matched with corresponding provision of environmental sanitation amenities (Afon, A.O. et.al, 2008). To determine how individuals behave when it comes to reducing risks associated with environmental health, four subscales evaluating student behaviors toward environmental health issues were analyzed: personal-level issues, food 
consumption practices and noise pollution, everyday recycling, and exercise. Results indicated that a person's attitude did predict whether a person engaged in behaviors that would reduce or eliminate the risk associated with environmental health issues. Additionally, there were knowledge and demographic variables that were determined to be significantly associated with two behavior subscales: food consumption practices and noise pollution, and everyday recycling (Dhitinut Ratnapradipa, 2011)

The sanitation behavior observed is in the form of a series of various forms of behavior/actions that people do toward garbage, including environmentally responsible behaviors such as environmental soiling actions to responsible actions such as actions to preserve and clean the environment.

\section{METHODS OF RESEARCH}

The population in this study is the entire housewives aged 30 to 60 years old in Semarang City. While the samples are 100 housewives aged 30 to 60 years from the Sumurboto, Ngesrep and Karang Bendo Administrative Village in Semarang City. The minimum sample size is using Eq. (1).

$$
n=\frac{(Z 1 / 2 \alpha) 2(\delta) 2}{(\varepsilon)}
$$

By the error rate $(\alpha)$ of $10 \%$, then $Z 1 / 2 \alpha=1.645,(\varepsilon)=0.1$, standard deviation $(\delta)=0.5$; so the minimum sample $(\mathrm{n})$ is 67.65 and is rounded to 100 respondents.

Sampling Technique and Data Collection Method. Sampling technique used in this research is non-probability sampling. Type of sampling used is purposive sampling. Purposive sampling is a sampling technique based on certain considerations; the selected samples in the study are housewives aged $30-60$ years. After the data are collected, the questionnaire is analyzed through its validity and reliability to get feasible data for the research.

In order to measure the validity test, questionnaire or indicator is said to be valid, if $r$ arithmetic $>r$ table, that is comparing Total Item value - Total Correlation with result of $r$ table calculation. Testing reliability with Cronbach alpha $(\alpha)$ statistical test. A construct / variable is said to be reliable, if it gives the value of cronbach alpha $(\alpha)>0.60$.

\section{RESEARCH MODEL AND HYPOTHESIS}

The first hypothesis, about the presence or absence of positive and significant impacts between knowledge variables on environmental hygiene maintenance behavior and second hypothesis about the presence or absence of positive and significant impact between perceptual variables on the behavior of environmental hygiene

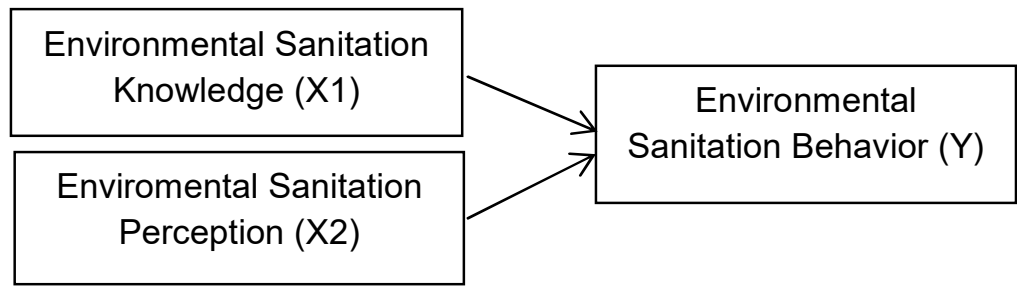

Figure 1 - Research Model

The research model shows the existence of 2 (three) hypotheses. The hypotheses in Figure 1, consisting of: (1) Knowledge of environmental hygiene has a positive and significant impact on environmental hygiene behavior, (2) Perceptions about environmental hygiene have a positive and significant impact on environmental hygiene behavior. 
Variable of research and indicator variable. The research variables and indicator variables as in Table 1.

Table 1 - Research variable and indicator variable

\begin{tabular}{|c|c|c|c|c|}
\hline No & Variable & Concept Definition & Indicator & $\begin{array}{l}\text { Measurement } \\
\text { Scale }\end{array}$ \\
\hline \multirow[t]{3}{*}{1} & \multirow{3}{*}{$\begin{array}{l}\text { Environmental } \\
\text { Sanitation } \\
\text { Knowledge (X1) }\end{array}$} & \multirow{3}{*}{$\begin{array}{l}\text { knowledge is the result of remembering a thing, } \\
\text { including recalling events that have been } \\
\text { experienced either intentionally or not } \\
\text { intentionally and this happens after people make } \\
\text { contact or observation of a particular object }\end{array}$} & $\begin{array}{l}\text { 1. knowing the danger of } \\
\text { pollution to human health } \\
\text { 2. knowing the dangers of } \\
\text { household waste on the } \\
\text { environment }\end{array}$ & \multirow{3}{*}{$\begin{array}{l}\text { Interval data with } \\
\text { Likert scale of } 1-5\end{array}$} \\
\hline & & & $\begin{array}{l}\text { 3. knowing a clean and } \\
\text { healthy environment }\end{array}$ & \\
\hline & & & $\begin{array}{l}\text { 4. knowing clean and } \\
\text { healthy food }\end{array}$ & \\
\hline \multirow{6}{*}{2} & \multirow{6}{*}{$\begin{array}{l}\text { Environmental } \\
\text { Sanitation } \\
\text { Perception } \\
\quad(\mathrm{X} 2)\end{array}$} & \multirow{6}{*}{$\begin{array}{l}\text { perception is a process of interpreting information } \\
\text { obtained through the human sense }\end{array}$} & $\begin{array}{l}\text { 1. perception about } \\
\text { environmental pollution }\end{array}$ & \multirow{6}{*}{$\begin{array}{l}\text { Interval data with } \\
\text { Likert scale of } 1-5\end{array}$} \\
\hline & & & $\begin{array}{l}\text { 2. perception about } \\
\text { household waste }\end{array}$ & \\
\hline & & & 3. perception about a & \\
\hline & & & $\begin{array}{l}\text { clean and healthy } \\
\text { environment }\end{array}$ & \\
\hline & & & $\begin{array}{l}\text { 4. perception about } \\
\text { healthy settlements }\end{array}$ & \\
\hline & & & $\begin{array}{l}\text { 5. perception about clean } \\
\text { and healthy food }\end{array}$ & \\
\hline \multirow{4}{*}{3} & \multirow{4}{*}{$\begin{array}{c}\text { Environmental } \\
\text { Sanitation Behavior } \\
(\mathrm{Y})\end{array}$} & \multirow{4}{*}{$\begin{array}{l}\text { behavior is an attitude that is born due to interaction } \\
\text { between humans and the environment, so that } \\
\text { individual and community behavior can affect } \\
\text { environmental conditions }\end{array}$} & $\begin{array}{l}\text { 1. sorting waste into } \\
\text { organic and inorganic }\end{array}$ & \multirow{4}{*}{$\begin{array}{l}\text { Interval data with } \\
\text { Likert scale of } 1-5\end{array}$} \\
\hline & & & $\begin{array}{l}\text { 2. consuming of healthy } \\
\text { and clean food }\end{array}$ & \\
\hline & & & $\begin{array}{l}\text { 3. maintaining a healthy } \\
\text { and clean environment }\end{array}$ & \\
\hline & & & $\begin{array}{l}\text { 4. avoiding environmental } \\
\text { pollution }\end{array}$ & \\
\hline
\end{tabular}

Testing Research Instruments:

Validity Test. Validity test is used to measure whether or not a questionnaire is valid (Ghozali, 2011). A questionnaire is declared valid if the question on the questionnaire is able to reveal something that the questionnaire will measure. Validity test is done by comparing between $r$ values counts with $r$ table. If $r$ count is greater than $r$ table and positive value then the item or question or indicator is declared valid and vice versa (Ghozali, 2011).

The amount of sample which was used in testing research instrument was 30 respondent with $\mathrm{df}$ (degree of freedom $)=\mathrm{n}-2=30-2=28$. On $5 \%$ error - range therefore, the value of $r$ tabel $=0,374$. The result of validity test is presented below.

Table 2 - Validity Test Result

\begin{tabular}{|c|c|c|c|c|}
\hline Variable & Item & R count & $\mathrm{r}$ table & Annotation \\
\hline Environmental Sanitation Knowledge (X1) & $\begin{array}{l}\text { Question } 1 \\
\text { Question } 2 \\
\text { Question } 3 \\
\text { Question } 4\end{array}$ & $\begin{array}{l}0.593 \\
0.385 \\
0.520 \\
0.388\end{array}$ & $\begin{array}{l}0.374 \\
0.374 \\
0.374 \\
0.374\end{array}$ & $\begin{array}{l}\text { Valid } \\
\text { Valid } \\
\text { Valid } \\
\text { Valid }\end{array}$ \\
\hline Environmental Sanitation Perception (X2) & $\begin{array}{l}\text { Question } 1 \\
\text { Question } 2 \\
\text { Question } 3 \\
\text { Question } 4 \\
\text { Question } 5\end{array}$ & $\begin{array}{l}0.667 \\
0.731 \\
0.685 \\
0.588 \\
0.385\end{array}$ & $\begin{array}{l}0.374 \\
0.374 \\
0.374 \\
0.374 \\
0.374 \\
\end{array}$ & $\begin{array}{l}\text { Valid } \\
\text { Valid } \\
\text { Valid } \\
\text { Valid } \\
\text { Valid }\end{array}$ \\
\hline Environmental Sanitation Behavior (Y) & $\begin{array}{l}\text { Question } 1 \\
\text { Question } 2 \\
\text { Question } 3 \\
\text { Question } 4\end{array}$ & $\begin{array}{l}0.383 \\
0.381 \\
0.600 \\
0.538\end{array}$ & $\begin{array}{l}0.374 \\
0.374 \\
0.374 \\
0.374\end{array}$ & $\begin{array}{l}\text { Valid } \\
\text { Valid } \\
\text { Valid } \\
\text { Valid }\end{array}$ \\
\hline
\end{tabular}

Source: Processed Primary Data, 2018.

The results of the validity test in table 2 shows that all question items used in this study have the value of $r$ count greater than the $r$ table ( $r$ count> 374). Therefore, it can be concluded that all the questions of each research variable can be said valid. 
Reliability Test. Reliability is a tool for measuring a questionnaire which act as an indicator of a variable or construct (Ghozali, 2011). A questionnaire is said to be reliable if one's response to a statement is consistent or stable over time. Respondent's answer to this question is said to be reliable if each question is answered consistently or the answer should not be random because each question wants to measure the same thing. If the answer to this indicator is random, then it can be said that it is not reliable. The test equipment used is Cronbach's Alpha. With the following conditions:

- If cronbach's alpha $(\alpha)>0,6$, then the questionnaire can be considered reliable.

- If cronbach's alpha $(\alpha)<0,6$, then the questionnaire can be considered unreliable. The results of reliability test, can be seen in Table 3 .

Table 3 - Reliability Test Result

\begin{tabular}{|c|c|c|c|c|c|}
\hline No & Variable & Cronbach's Alpha & Sign & Standard Value & Annotation \\
\hline 1 & Environmental Sanitation Knowledge (X1) & 0.681 & $>$ & 0,60 & Reliable \\
2 & Environmental Sanitation Perception (X2) & 0.790 & $>$ & 0,60 & Reliable \\
3 & Environmental Sanitation Behavior (Y) & 0.666 & $>$ & 0,60 & Reliable \\
\hline
\end{tabular}

Source: Processed Primary Data, 2018.

The results of reliability tests in table 3 showed that all variables in the study has a value of cronbachs alpha greater than 0.60 so it can be said all the measuring concepts of each variable of the questionnaire is reliable which means that the questionnaire used in this study is a reliable questionnaire.

Data Analysis Technique. To prove the first hypothesis, about the presence or absence of positive impact and significance between knowledge variable about environmental sanitation to environmental sanitation behavior and second hypothesis about the presence or absence of positive impact and significance between perception variable about environmental sanitation to environmental sanitation behavior, multiple linear regression analysis tool was used.

In order for multiple linear regression models to be used in this study, normality test and classical assumption test consist of heteroskedasticity, and multicollenearity test. Based on the calculations it fulfills the classical assumption.

\section{RESULTS AND DISCUSSION}

Equations of multiple linear regression lines based on calculations using SPSS version 22 obtained the following results:

Table 4 - Multiple Linear Regression

Coefficients $^{\mathrm{a}}$

\begin{tabular}{|c|c|c|c|c|c|c|c|}
\hline \multirow{2}{*}{ Model } & \multicolumn{2}{|c|}{ Unstandardized Coefficients } & \multirow{2}{*}{$\begin{array}{c}\text { Standardized Coefficients } \\
\text { Beta }\end{array}$} & \multirow{2}{*}{ T } & \multirow[b]{2}{*}{ Sig. } & \multicolumn{2}{|c|}{ Collinearity Statistics } \\
\hline & $\mathrm{B}$ & Std. Error & & & & Tolerance & VIF \\
\hline (Constant) & 1.656 & .744 & & 2.228 & .028 & & \\
\hline Knowlegde & .840 & .046 & .882 & 18.382 & .000 & 875 & 1.143 \\
\hline Perception & .025 & .031 & .039 & .820 & .414 & .875 & 1.143 \\
\hline
\end{tabular}

a. Dependent Variable: Behavior

Source: Processed Result of SPSS version 22 with Primary Data, 2018.

Multiple Linear Regression Equation based on the table 4 can be seen in Eq. (1).

$$
Y=1,626+0,840 \times 1+0,025 \times 2+e
$$

From the multiple linear regression analysis above it can be seen that the regression coefficient between knowledge about environmental sanitation (X1) to environmental sanitation behavior $(Y)$ is 0.840 with significance of 0.000 . This means there is a positive and 
significant influence, meaning that with knowledge about good environmental sanitation will increase the behavior of environmental sanitation significantly (meaning). Regression coefficient between perception about environmental sanitation (X2) to environmental sanitation behavior $(Y)$ equal to 0,025 with significance 0,414 . This means that there is a positive and insignificant effect (because sig <0,05), meaning perception of good environmental sanitation will improve environmental sanitation behavior but not significant (meaningless).

Classical assumption test consisting of normality test, heteroskedasticity test and multicollinearity test have fulfilled the requirement that multiple linear regression analysis can be used to analyze this research.

\section{CONCLUSION AND SUGGESTIONS}

The result of multiple linear regression analysis shows that: (a) there is positive and significant influence between knowledge about environmental sanitation to behavior for environmental sanitation, (b) there is a positive and insignificant influence between the knowledge of environmental sanitation to behavior for environmental sanitation

Based on the responses of housewives about the knowledge, perception and behavior of environmental sanitation in the discussion, it is suggested: (a) The impact of perceptions on behavior that is not significant, so it needs to give understanding and understanding about environmental sanitation to the community, (b) There needs to be counseling about environmental sanitation especially related to household waste because many of housewife who have not done waste segregation to be organic and inorganic, and (c) the need for counseling about public health with less clean environmental conditions

Recommendations in this study include: (a) the need to be counseling about environmental sanitation especially about pollution and clean \& healthy food, (b) the need to be counseling about environmental sanitation especially related to household waste, c) the need for counseling about public health.

\section{REFERENCES}

1. Acheampong, P. T. (2010). Environmental Sanitation in the Kumasi Metropolitan Area. A Master of Science. Thesis Submitted to the Department of Planning. Kwame Nkrumah University of Science and Technology, pp. $1-5$. Assessed at http://acedemia.com, 19/10/2017.

2. Ajiboye, J. O. \& Ajitoni, S. O. (2008) Effects of full and Quasi-Participatory Learning Strategies on Nigerian Senior Secondary Students' Environmental Knowledge: Implications for Classroom Practice. International Journal of Environmental and Science Education, 3 (2), 58-66.

3. Anijaobi-Idem. Et.al, 2015. Environmental Awareness and School Sanitation in Calabar Metropolis of Cross Rivers State, Nigeria. Journal of Education and Practice www.iiste.org ISSN 2222-1735 Vol.6, No.4, 2015, p.68-71. (Paper) ISSN 2222-288X (Online)

4. Afon, A. O, Okanlawon, S. A, Adigun F. O \& Odunola Ladoke Akintola (2008). Evolving sustainable environmental sanitation behaviour among secondary school students: home and school as correlated in Ogbomoso, Nigeria. University of Technology, Ogbomoso, Nigeria. WIT Transactions on Ecology and the Environment, Vol 117, (C) 2008 WIT Press. www.witpress.com, ISSN 1743-3541 (on-line)

5. Aswathy S K (2015). Knowledge And Practice Regarding Environmental Sanitation And Hygiene Among General Population: A Cross Sectional Survey. GJRA - Global Jurnal for Research Analysis. Volume-4, Issues-11, Nov-2015, ISSN No 2277-8160, p 158-159

6. Byoung, Suk Kweon, et.al (2006). Large-Scale Environmental Knowledge Investigating the Relationship Between Self-Reported and Objectively Measured Physical Environments. Environment And Behavior, Vol. 38 No. 1, January 2006. p.72-91 DOI: 10.1177/0013916505280092 @ 2006 Sage Publications 
7. Dhitinut Ratnapradipa, Stephen L. Brown, Wendi K. Middleton, and Alicia B. Wodika, (2011). Measuring Environmental Health Perception Among College Students. The Health Educator. Fal1 2011, Vol. 43, No.2.

8. Ghozali, I, (2011). Aplikasi Analisis Multivariat dengan Program IBM SPSS Versi-19. Semarang: Badan Penerbit UNDIP, ISBN 979.704.015.1, Cetakan V, April 2011.

9. Henewa, R. A., Bolawole Raheem \& Aeyaw, Y (2014). Impact of Environmental Education on Sanitation Practices in Some Selected Schools in the New Juaben Municipality Eastern Region of Ghana, I.J.A.B.R, Vol. 4(2) 2014: 228-234. ISSN 2250 3579, p 228- 234.

10. Igwe, P.U.; Okezue, W.I.; Nwaduru, C.L.; Ezebuka, O.A.; Ginikanwa, P.A. (2017). A Review of Students' Perception of Environmental Sanitation. International journal of Rural Development, Environment and Health Research (IJREH) [Vol-1, Issue-4, Nov-Dec, 2017, p.29-37] https://dx.doi.org/10.22161/ijreh.1.4.5 ISSN: 2456-8678

11. Ministry of Local Government \& Rural Development (2010). Ghana's Revised Environmental Sanitation Policy. Accra: MLGRD.

12. Morelli, J. (2011). Environmental Sustainability: A Definition for Environmental Professional. Journal of Environmental Sustainability, 1(1 ):5-8

13. Nazaruddin (2014). Analisis perilaku masyarakat dalam upaya menciptakan kebersihan lingkungan di kota pekanbaru (studi kasus kelurahan simpang baru). Jom FISIP, Volume 1 No. 2. October 2014, pp. 1-15.

14. Notoatmodjo S, (2007). Ilmu Kesehatan Masyarakat. Jakarta: Rineka Cipta

15. Oluwole Daramola, Akintayo Ojo, Similoluwa Joel (2016). Environmental Sanitation Perception and Practices of the Disposal of the Dead in the lle - Ife City, Nigeria. International Journal of Academic Research in Environment and Geography. Vol. 3, No. 1, January, 2016, pp. $15-23$.

16. Ririn Setyowati, Surahma Asti Mulasari (2013). Pengetahuan dan Perilaku Ibu Rumah Tangga dalam Pengelolaan Sampah Plastik. Kesmas, Jurnal Kesehatan Masyarakat Nasional. Vol. 7, No. 12, July 2013, pp. 562-566

17. World Health Organization, (WHO) (2008). Global Water Supply and Sanitation Assessment 2000 Report. World Health Organization, Geneva. 